\title{
Names as Repositories of Worldview: Empirical Evidence from the Morphological and Semantic Analysis of Tiv Personal Names
}

\author{
Titus Terver Udu \\ Department of Arts and Social Sciences Education \\ Benue State University, Makurdi \\ Nigeria
}

\begin{abstract}
Research in names and naming practices is gaining more grounds globally and the outcomes have been diverse. Despite this, there seems to be a consensus viewpoint that the primary reason for assigning names to people, places and things is to give them identity. While this well-known fact is recognized, the purpose of the present article is to examine the phenomenon of worldview as expressed in personal names. The article looked at the questions: Does the study of the internal structure of personal names in any way add to our understanding of the meaning and motive of such names? Or does it reveal any significant information about the bond between language, thought, and sociocultural practices? Data were drawn from oral and literature sources and analyzed descriptively. The approach involved critically examining the syntactic and semantic features of sampled personal names and making informed observations about them. The outcome of the analysis showed that Tiv philosophy and worldview are expressed in personal names and other oral genres of language such as proverbs and wise sayings.
\end{abstract}

Keywords: Tiv, personal names, worldview, patronymic reference, compounding

\subsection{About the Tiv People}

The word 'Tiv' represents both an ethnic group and the name of a language. Tiv is a splinter group of the Bantu, and belongs to the Niger-Congo language phylum. On the linguistic map of Africa, the Tiv people are found in Nigeria and the Cameroon Republic. Much has been written about the Tiv people as noticeable in the works of Abrahams (1940), Rubingh (1969), and a host of other indigenous scholars such as Gbor (1978), Makar (1994), Iyortyom (1993), and Udu (2009). Tiv is a tribe with over six million speakers spread across 33 local government areas in five states of Benue, Taraba, Nasarawa, Plateau, Cross River and the Federal Capital Territory of Nigeria. In the Republic of Cameroon, the Tiv people are found in Akwaya sub-division, Manyu, Southwest Province. This population puts the Tiv ethnic tribe as the fourth largest after Hausa, Ibo and Yoruba. The Federal Government of Nigeria has accorded Tiv the status of a network broadcast language alongside Nupe, Fulfulde, Kanuri, Ibibio, Izon, Edo, Urhobo, Igala and Annang. With the orthography of Tiv fully developed and approved by the Federal Government of Nigeria, Tiv literature and publications of various kinds and importance keep increasing. The Tiv people have two bilingual dictionaries authored by two Europeans namely Marherbe (1931) and Abrahams (1940) and a couple of others authored by indigenous scholars. The Tiv Bible and hymnals were pioneered by the Dutch Reformed Church Mission. Tiv language is taught and learnt in schools including higher institutions in Benue State-owned Colleges of Education, at Katsina-Ala and Oju, and Benue State University, Makurdi, Nigeria. Tiv is also used as a language of trade, religious worship and daily communication.
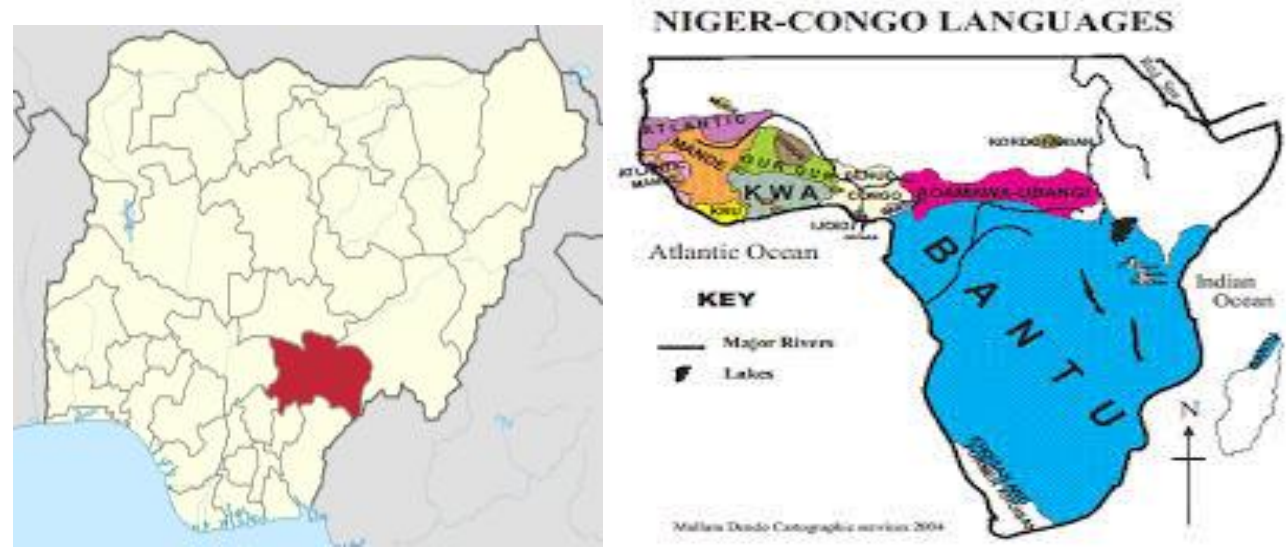

Maps showing the Location and Classification of Tiv Language 


\subsection{Studies on Names and Naming Practices}

Personal names and naming practices are a much sought-after subject matter in research. In all human cultures, every newborn is given a name, which serves as an identity mark. Among the Akan people of Ghana, Adomako (2017) makes a claim that every child is given at least two personal names: the kradin (which stands for day-name) and abusuadin (which denotes family name). In Ibibio, an ethnic group in South-Eastern Nigeria, names reveals the religious beliefs of an individual, the status of his family, the calendar of the people, their commercial activities, their geography in terms of land classification, seasons and the philosophical concepts (Ansa \& Okon, 2004). Names are reflective of the cosmology or worldview of the people. Tiav (2012) describes names as significant signposts of information about the origin, background and beliefs of a people. Through names, individuals relate and interact with the world around them. In general, names tell us about man and his environment and how man sees the world and reacts to it (Meiring,1993). With names, things, places, and persons become classified and ordered according to the culturally specific principles of division and association (Angel, Arbelaez \& Cisneros, 2012). According to Windt-Val (2012), names and naming constitute important parts of the work of the building of a nation and there is a connection between a person's given name and their feeling of identity and self. Windt-Val (2012) further states that the way people use personal names constitutes an important part of the impression they want other people to form of ourselves. Interpol (2006) maintained that names are a valuable source of information indicating gender, marital status, birthplace, nationality, ethnicity, religion, and position within a family or even within a society. Personal names serve as repositories of socio-cultural, religious, political and other traditional values of the people (Uko, 2004). Drawing examples from Nigerian communities, Tiav (2012) avers that:

...the practice of naming has greater social significations than merely giving an individual a nomenclature. First, through names, individuals relate and interact with the world around them. Second, a name provides elemental evidence of a person's being or humanness - some rudimentary information on the background of the bearer. Third, a name could be a philosophical statement and a means of acting on the world (p.165)

The role of names as historical and cultural landmarks is not new. In Africa, many historical events are sometimes summarized and relayed in personal names and place names. Africans give names to remind them of particular life incidents - whether pleasant or unpleasant, whether momentous or ordinary. Ansa and Okon (2004) describe place names and personal names as "...undocumented historical records and landmarks to be passed on from generation to generation" (p.183).

The same is true about the Tiv people. Among the Tiv people, borrowed names such as Damkor (original Hausa word, Dankor), Gawan (Gowon)Waya (wire/ telephone), Abaji all give a bird's eye view of Tiv contact with neighbouring tribes and the influence the languages of such tribes have on Tiv language. The defeat of the renowned Hausa warrior, Dankaro many decades ago was the main reason why some Tiv families named their male children Damkor (Dankaro) in commemoration of the incidence. Similarly, borrowed names from Hausa such as Adamu, Audu, and Kachina are part of Tiv culture today. Another important example is with the English name Malherbe, the first missionary to develop a Tiv-English bilingual dictionary. The first Tiv man to bear Malherbe was in Tombo, the area the missionary first settled. The birth of Malherbe Andiir Gur coincided with the peak of the Rev. W.A. Malherbe's missionary work in Tombo area. This made the family to name the boy after this missionary. Similar examples can be drawn. Many Tiv children born during the reign of General Yakubu Gowon were named Gawan. During his reign as Nigerian Head of State, General Yakubu Gowon was widely known and respected for his gallantly, which culminated to the defeat of the Biafran Army. So Tiv families who wanted to not only remember his exploits but also identify with Gen. Gowon named their children Gawan (the Tiv versin of Gowon). Iyortyom (1993) recalls that in the olden days, the act of assigning names to the newborn was the exclusive privilege of the old or head of the family. New names were given to reflect the current event, or it could be a plea or an appeal or an accusation to the child's igba or ityo. Tiv people also gave and still give their pet animals names to reflect their opinion or attitude to the world or events as they occur. This will be looked into in greater detail in the section on names and worldview.

\subsection{Theoretical Framework}

The linguistic feature of names has been recognized in research. Mpande (2006) talks of names as being the most meaningful lexicon in the vocabulary of any language and an important part of language inventory. In grammar, proper names (names of people and places) are classified under noun category (Amalsaleh \& Abdollahi, 2015). When people enquire to know the meaning of names, the answers they get reveal a great deal about the relation between thought, language and meaning. Meiring (1993) states that the way in which man names rivers, mountains, valleys, towns and other environmental entities reflects how he thinks and lives and what his psychological disposition and subsconsious mind produces in his daily contact with universal semantics. 
Tiav (2012) maintains that "names do not only represent nomenclatures and identify items, but they are also linguistic and communicative acts that express some functional, aesthetic and assertive meanings and features." (p165). After examining the various functions of names, theis paper considered the theory of linguistic determinism relevant to anchor its discussion. The proponents of this theory argue that language determines thought and thought is related to culture. At the same time, thought processes are influenced by language to a certain degree. Ideas regarding the theory of linguistic determinism emanate from the works of Wilhelm von Humboldt, Edward Sapir and Benjamin Lee Whorf. Linguistic determinism is the idea that the things a person thinks are fully determined by the language that they speak (O'Donnel, 2008). In other words, individuals experience the world based on the structure of the language they habitually use. Humboldt summarized this position by stating that language completely determines thought and thought is impossible without language. His popular words are: "Language is by no means a mere means of communication, but the mirror of the mind and of the world view of the speaker" (Humboldt from Gesammelte Schriften VI, p.23 quoted in Koerner 2007:272). In support of this view, Sapir (1956) and Whorf (1956) maintained that language predetermines what we see in the world around us. This theory is relevant to this article in the sense that the author views the act of naming people and places as a way of representing the feelings, beliefs, and interpretations the people have about the world around them. In other words, language not only relates to culture, it holds significant influence on how the people perceive the world and the things around them.

\subsection{Personal Names and Tiv Worldview}

It is common to refer to worldview as the broad set of beliefs, attitudes and ideas about life and the world. While Kraft (1989, p.20) describes worldview as "culturally structured assumptions, values, and commitments underlying a people's perception of reality," Gousmett's (1996) calls it "the comprehensive framework of one's basic beliefs about things and their relationships" (p.2). Gousmett lists the elements that form the basis for worldview to include God, human life, the meaning of suffering, family relationships, morality, and the significance of rainbows. No one will doubt that language is a key component in expressing a people's worldview. Language is at the centre of man's relationship with God and his fellow man and in the interpretation of the conditions about this life. Language influences man's belief and thought processes.

The Tiv people express their worldview through various genres of language namely proverbs, wise sayings, and personal names. Much has been researched about Tiv proverbs and wise sayings (Adeiyongo, 2004), Sam-Paddy (2017) but little has been done regarding Tiv personal names and place names. In Tiv culture, a child is named immediately after birth. He/she can be given an already existing name or a name that is completely new. Male children can be named after their fathers while female children can be named after their mothers but not in reverse order. Names such as Nguvan (meaning he/she is coming), Nguwasen (meaning he/she is rendering help), Ngunan (meaning he/she will provide) are clearly feminine-specific. In a few cases, some names can be borne by both male and female children. As already noted, the people's beliefs and philosophies of life significantly influence the way they name their new born. Beliefs in the power of death and associated misfortunes can be expressed through the following names: Swende (accidental death), Aaikyôr (accident), Ishômwua (murdered by a machete), Ishômkase (surrounded by machete), Kuwua (killed by death), Kukase (surrounded by death), Kukighir (suppressed by death), Kutim (exterminated by death), Kukegh (lay siege by death), Terkimbi (compensated by God), Terkumbur (comforted by God). Tiv traditionalists are more attuned to giving their children such names as Ityohemba (the Ityo are supreme), Tsavwua (killed by witchcraft), Atsuku (kind of fetish or idol). In contrast, a Tiv man of the Christian faith would give such names as Terhemba or Aôndohemba (God is supreme), Teryima or Aôndoyima (saved by God), Oryiman (saviour), Orsurumshima (comforter), Iyuana (his gift) etc.

On the reverence and respect accorded womenfolk, given names such as Kasevkyundu (compared to twenty women), Kasevhemba (women are the greatest), Ishanpepe (morning star), Torkwase (queen), Kumashe (beauty) go to show the value Tiv people generally attach to the role played by women in society. A woman does not necessarily need to be a king's wife or of royal lineage before she can be named Torkwase (queen). She is given the name out of fondness or reverence for the dignity of women. Furthermore, it is not be seen as strange that the Tiv people bear animal names. Such names denote the strength and nobility these animals are known for. Thus Tiv people bear such names as: Nor (elephant or hippo), Anyam (tiger), Ambe (crocodile), Igyuve (eagle), Begha (lion), Nyinya (horse).

\subsection{Methodology}

The research design used in this paper was a descriptive survey in which data were collected through oral sources and library research. Tiv personal names with free and bound morphemes were identified through the media already stated above and analyzed morphologically. The interpretation of the data was based on the researcher's broad knowledge of linguistics. 


\subsection{Reasons for Choosing Certain Names}

Tiv names are not just given. There is always a reason and meaning attached to names. The following are some of the reasons for choosing certain names.

(i) To express a philosophy of life, attitude to life and the perception of life happenings. Mluwamkuman (I am contented the way I am)

Orkaishima (the heart makes a man)

Mnguaorga (I have no helper)

More of this can be seen in names given to pets especially dogs.

\begin{tabular}{|l|l|l|}
\hline S/N & Name & Meaning \\
\hline 1 & Oriyou & Be concerned about your affairs, not of others \\
\hline 2 & Orkpeikyandega & Emaciation does not necessarily mean you are going to die \\
\hline 3 & Dooamoshazwa & Only pays lip service, the heart is far away from me \\
\hline 4 & Iorveyaakaave & They should take what belongs to them \\
\hline
\end{tabular}

(ii) To define man's relationship with his creator. The Tiv people recognize God as the creator of the universe and his powers over the natural elements such as the sun, the wind, and water. This is expressed in names such as:

Orkainya (man is dust)

Iyangedue (the sunrise)

Ushanengen (the Most High sees)

Targema (the world has changed)

(iii) To express cultural beliefs. To the Tiv people, the entire world is controlled by ityo(father's kinsmen) and igba (mother's kinsmen), God's main agents on earth. To them God has given igba and ityo powers over death-to cause it or to stop it. This is expressed in personal names such as:

\begin{tabular}{|l|l|l|l|}
\hline S/N & Name & noun+noun & Meaning \\
\hline 1. & Igbawase & Igba+wase & Helped/assisted by maternal kinsmen \\
\hline 2 & Igbayima & Igba+yima & Saved/delivered by maternal kinsmen \\
\hline 3 & Igbahemba & Igba+yima & None is as powerful, helpful as maternal kinsmen \\
\hline
\end{tabular}

See also

\begin{tabular}{|l|l|l|l|}
\hline S/N & Name & noun+noun & Meaning \\
\hline 1. & Ityowase & Ityo + wase & Helped/assisted by paternal kinsmen \\
\hline 2 & Ityoyima & Ityo + yima & Saved/delivered by paternal kinsmen \\
\hline 3 & Ityohemba & Ityo + hemba & None is as powerful, helpful as maternal kinsmen \\
\hline
\end{tabular}

With the influence of Christianity, some Tiv personal names are given to convey belief in the sovereignty, omnipresence and omnipotence of God. The alternative names of God in Tiv are Aôndo (God), Ter(God the father), Tor(God the king of kings), and Usha (God the most high). Large examples are as follows:

\begin{tabular}{|l|l|l|l|}
\hline S/N & Name & Noun+verb & Meaning \\
\hline 1. & Aôndowase & Aôndo+wase & Helped/assisted by God \\
\hline 2 & Aôndoyima & Aôndo+yima & Saved/delivered by God \\
\hline 3 & Aôndohemba & Aôndo+hemba & None is as powerful, helpful as maternal kinsmen \\
\hline $\mathbf{S} / \mathbf{N}$ & Name & Noun+verb & Meaning \\
\hline 1. & Terwase & Ter+wase & Helped/assisted by God the father \\
\hline 2 & Teryima & Ter+yima & Saved/delivered by God the father \\
\hline 3 & Terhemba & Ter+hemba & None is as powerful, helpful as God the father \\
\hline
\end{tabular}

\begin{tabular}{|l|l|l|l|}
\hline S/N & Name & Noun+verb & Meaning \\
\hline 1. & Torwase & Tor+wase & Helped/assisted by God the king of kings \\
\hline 2 & Toryima & Tor+yima & Saved/delivered by God the king of kings \\
\hline 3 & Torhemba & Tor + hemba & None is as powerful, helpful as God the king of kings \\
\hline
\end{tabular}

\begin{tabular}{|l|l|l|l|}
\hline S/N & Name & noun+verb & Meaning \\
\hline 1. & Ushawase & Usha+wase & Helped/assisted by God the most high \\
\hline 2 & Ushayima & Usha+yima & Saved/delivered by God the most high \\
\hline 3 & Ushahemba & Usha+hemba & None is as powerful, helpful as God the most high \\
\hline
\end{tabular}


God-given power to cause pain, affliction, change human fortune, and even bring about death is called tsav (witchcraft). So, belief in tsav could influence the naming of persons such as:

\begin{tabular}{|l|l|l|l|}
\hline S/N & Name & Noun+verb & Meaning \\
\hline 1. & Tsavwase & Tsav+wase & Helped/assisted by maternal tsav \\
\hline 2 & Tsavyima & Tsav+yima & Saved/delivered by tsav \\
\hline 3 & Tsavhemba & Tsav+hemba & None is as powerful, helpful as tsav \\
\hline
\end{tabular}

(iv) Names are given to express cherished human virtues. Belief in virtues of hard work, love for one another, being peaceful, showing kindness, being honest, virtuous, etc. could influence the giving of such names as:

\begin{tabular}{|l|l|l|l|}
\hline S/N & Name & Adj+noun & Meaning \\
\hline 1. & Tavershima & Taver+shima & Determination; be determined; unwavering \\
\hline 2 & Viashima & Via+shima & Unrelenting; self-willed \\
\hline 3 & Dooshima & Doo+shima & Love \\
\hline 4 & Bemshima & Bem+shima & Peace \\
\hline
\end{tabular}

(vi) To express given circumstances. Twins can be given the names Hemen (the first of the twin to appear) and Dondo (the last to be born). The name Ityavwua is given to remind a family that a member was killed during war.

\subsection{The Structure of Tiv names}

An analysis of the inner structure of Tiv personal names is very useful in understanding both denotative and connotative meaning of such personal names. First, let us look as personal names with simple and compound structures.

\subsubsection{Simple vs compound name(ing)}

Tiv names with simple structures have only one free morpheme. In other words, such names do not have affixes and they are very easy to pronounce. Most simple names are concept names, which are metaphors of something else. Examples include:

Ishima (heart).

Gbenda (road)

Ikyô (forest)

Gbande (drum)

Jubu (socks)

All the above names are borne by human beings. It can be clearly seen that they serve referential function as they denote names of objects or things.

Tiv personal and place names could also take a compound structure. Compound names are made possible by joining two or more words to make a single name.

\begin{tabular}{|l|l|l|}
\hline S/N & Tiv & English \\
\hline
\end{tabular}

Free morpheme + free morpheme

\begin{tabular}{|c|c|c|c|c|c|}
\hline Aôndo & + & hemba & $=$ & Aôndohemba & (Godwin) or (God wins) \\
\hline Ter & + & hemba & $=$ & Terhemba & (God the father wins) \\
\hline Usha & + & hemba & $=$ & Ushahemba & (God the most high wins) \\
\hline Tor & + & hemba & $=$ & Torhemba & (God the king of king wins) \\
\hline
\end{tabular}

The above shows noun+verb structure. All two morphemes are of the free type.

The names below have more intricate structures.

Ngulianga (easily identifiable)

Kwaghsaanga (Truth must be revealed)

$\mathrm{Ngu}+$ lian+ga $=$ Ngulianga

Is+identify+not

(He/she is easily identifiable)

Kwagh+saan+ga $=$ Kwaghsaanga

Thing+lost+not

(truth must be revealed someday)

Names with simple and compound structures are not peculiar to Tiv alone. Such features have been found in Persian language and reported by Amalsaleh and Abdollahi (2015) and in Nordic and reported by Baptisa, Batisa and Mamede (2006). The formation patterns are however not the same. 


\subsection{Other features of Tiv Personal Names}

\subsubsection{Patronymic names in Tiv}

Patronymic names are those that derive from the personal names of a father (Interpol, 2006) and reveal important family ties. The female-specific prefixes wan and an are markers of personal names after the father. Wan and an are alternate forms. These prefixes are used almost always with reference to married women. When so used, the root of the name signifies the name of the woman's father.

$\begin{array}{lllll}\text { Wan } & + & \text { Iorapuu } & = & \text { Waniorapuu (daughter of Iorapuu) } \\ \mathrm{An}+ & \text { Iorapuu } & = & \text { Aniorapuu }(\text { daughter of Iorapuu) } \\ \text { Wan }+ & \text { Torkunde } & = & \text { Wantorkunde (daughter of Torkunde) } \\ \mathrm{An}+ & \text { Torkunde } & = & \text { Antorkunde (daughter of Torkunde) }\end{array}$

Note: A careful look shows that all the names above have a noun+noun structure

\subsubsection{Morphemes with Metronymic Reference}

$\begin{array}{lllll}\text { Noun }+ & \text { verb structure } & & \text { final word } & \\ \text { Igba }+ & \text { wase } & = & \text { Igbawase } & \text { (helped/assisted by mothers' kinsmen) } \\ \text { Igba }+ & \text { yima } & = & \text { Igbayima } & \text { (saved by mother's kinsmen) } \\ \text { Igba }+ & \text { wua } & = & \text { Igbawua } & \text { (killed by mother's kinsmen) } \\ \text { Igba }+ & \text { doo } & = & \text { Igbadoo } & \text { (mother's kinsmen are a big asset) } \\ \text { Igba }+ & \text { hemba } & = & \text { Igbahemba } & \text { (none is greater than mother's kinsmen) }\end{array}$

\subsubsection{Generic Personal Names}

Consider the following examples which denote gender and interface with spelling

A large number of Tiv given names have male-specific and female-specific reference

$N g \hat{o}+h e m b a=N g \hat{o} h e m b a$ (none is greater than a mother)

$N g \hat{o} \quad+u n d u \quad=N g \hat{o u n d u}$ (left by the mother)

In the above examples, the morpheme with female-specific reference is $n g \hat{o}$ (mother)

Tor $\quad+d u e=$ Tordue (a king has emerged)

Tor $\quad+$ venda $=$ Torvenda (prohibited by the king)

In the above examples, the morpheme with male-specific reference is tor (king)

\subsubsection{Personal Names with the Feature of a Sentence}

Pink and Thomas (1970) describe a sentence as a group of words that makes a complete sense. A sentence may express (a) a statement; (b) a question; (c) a desire; and (d) an exclamation. A sentence has two basic parts: subject and predicate. Many Tiv personal names have all these elements. Tiv personal names contain elements that indicate the three moods of verbs namely, indicative, imperative and subjunctive.

(a) Names with indicative mood elements make statements or ask questions as the examples below:

$\mathrm{M}+\mathrm{mem}=\mathrm{Mmem}$

I+rest

(I rested or I refrain)

Families who have got the number of children they desire can give the last child the name Mmem.

M+rumun=Mrumun

I+agree

(I agree)

The name Mrumun shows that the family have accepted the gift of a child with all accompanying circumstances; whether male or female, whether born with abnormality or not. Both Mmem and Mrumun as names with sentence elements follow the subject+verb $(\mathrm{S}+\mathrm{V})$ order.

$\mathrm{M}+\mathrm{mem}$

M+rumun

$\mathrm{S}+\mathrm{V}$

$\mathrm{M}+$ ngu+ a+ nyi $=$ Mnguanyi

I +have+a+ what

(What do I have?)

M+tagher+or+nyi =Mtagherornyi (In what way am I a hindrance to anybody?)

I+obstructed+someone+what

(In what way am I a hindrance to anybody?)

$\mathrm{Or}+\mathrm{fe}+\mathrm{ga}=$ Orfega $($ nobody knows [tomorrow])

Body+know+not 
(Nobody knows [tomorrow)

Môtvihin+ze =Môvihinze (none is so bad to be rejected)

None+bad+not

(None is so bad to be rejected)

M+venda + ga $=$ Mvendaga

I+object+not

(I have no objection[to what God has decided])

Mvendaga is the opposite name to Mrumun.

(b) Personal names with imperative mood element are used for commands or for making entreaties.

Kwagh+la+ a+de $=$ Kwaghlaade

Thing+that+should+stop

(That should [thing] stop)

The above name is a form of prayer to God not to allow calamity to continue to befall a family.

Kwagh+la+a+er $=$ Kwaghlaaer

Thing+that+should+happen

([let] that thing come to pass)

De+vaan= Devaan

Stop+crying

(Stop crying)

De+zamber $=$ Dezamber

Stop+begging

(stop begging)

(c) Personal names with subjunctive mood elements express desire

$\mathrm{Ma}+\mathrm{i}+\mathrm{lu}+\mathrm{mo}=$ Mailumo

Could+have+be+me

(It could have been me or I wish I were the one)

Aôndo+a+ver= Aôndoaver

God+bless

(May God bless)

Examples of Personal names that show kinship ties

Angbian + doo $=$ Angbiandoo

Brother/sister+good

(A brother/sister is an asset)

Ter+doo=Terdoo

Father+good

(A father is an asset)

$\mathrm{Ngô}+\mathrm{doo}=\mathrm{Ng} \hat{o}$ doo

Mother+good

(A mother is an asset)

Wan+doo $=$ Wandoo

Son/daughter+good

(A son/daughter is an asset)

Forenaming as royalty and wealth

Shagbaor (man of means)

Tordue (king designate)

Kator (king designate)

Tiv personal names that denote cherished societal values

Ishimataver (determination)

Mhôônom (compassion)

Dooshima (love)

Bemshima(tender heart )

Viashima (stong-willed)

\subsubsection{Order of Tiv names}

(a) Terver Udu Anum Saave Akura Jima.

(b) Shidoo Iorfa Zaki Gaabu Anôngo Saave Akura Jima. 
(a) and (b) above represent the ideal order of Tiv personal names. In such order, personal names begin with the person's given (or adopted) name followed by the patronymic (family) name (in the case of boys and men) or husband's name (in the case of married women). With the order of Tiv names, one can easily tell the family ancestry to which someone belongs. Looking at (a) above, one can say Terver is the son of Udu, son of Anum, son of Saave, son of Akura who is the son of Jima. In (b), Shidoo is the daughter of Iorfa, son of Zaki, son of Gaabu, son of Anôngo son of Akura who is the son of Jima.

\subsection{Summary of Observations Arising from the Study}

The following constitutes a summary of the main findings of our study.

1. Tiv personal names and pet names are given to new born based on Tiv worldview and philosophy of life.

2. Cherished values and norms are promoted through the process of forenaming.

3. Like in English, all Tiv personal names and place names start in capital letters.

4. The Tiv people name their children immediately after birth.

5. Children can be named after their forefather's or mother's name.

6. Tiv names have simple and compound structures.

7. The Tiv people bear names borrowed from other cultures especially Hausa and English. This is evidence of Tiv having contact with these cultures as well as evidence that languages change over time. One key area this can be observed is in naming practices.

8. Some Tiv personal names have noun+noun structure, while others have free and bound morphemes.

9. Some Tiv personal names have noun+verb structure while others have adjective+noun structure.

10. Many Tiv names are expressed in full sentences such that some can take the form of declarative, interrogative, or imperative statements.

11. Some Tiv names are based on historical happenings and can denote particulate incidents in life.

12. The Tiv people also bear animal names.

13. The Tiv people bear names, which are metaphors of other things.

14. The feature of negation is expressed in Tiv names.

\subsection{Conclusion}

The paper demonstrates the interplay between onomastics and linguistics. It has been able to provide analysed data, which shows that the linguistic components of personal names in an important determinant of denotative and connotative meaning of such names. Furthermore, personal names are significant signposts of the worldview of the Tiv people. From the paper, the inextricable relations involving language, thought and culture came out prominently as the summarized results have shown. Further to the usefulness of the study, the author is able to empirically show that the use of borrowed personal names is an indication that Tiv language has contact with other languages namely Hausa and English. No study known to the author has done such an in-depth linguistic analysis of Tiv personal names.

\section{References}

Abraham, R.C. (1940). The Tiv people. London: Crown Agents.

Adomako, K. (2017). Morphophonological analysis of Akan female family name formation. Ghana Journal of Linguistics, 6(1), 1-32.

Amalsaleh, E., \& Abdollahi, M. (2015). Syntactic and semantic features of Persian proper names: A gender-based study. American International Journal of Contemporary Research, 5 (1), 103-108.

Angel, M.H., Arbelaez, S.M., \& Cisneros, S.P. (2012). Geographies of the name: Naming practices among the Muisca and Páez in the Audiencias of Santafé and Quito, Sixteenth and Seventeenth Centuries. Journal of Latin American Geography, Volume 11, Special, 91-115.

Ansa, S.A., \& Okon, B.A. (2004). Names as cultural identity: A sociolinguistic investigation of the Ibibio. International Journal of Linguistics and Communication, maiden edition. 182-190.

Baptista, J., Batisa, F., \& Mamede, N. (2006). Building a dictionary of anthroponyms. R. Vieira et al. (Eds.): PROPOR 2006, LNAI 3960, pp. $21-30$.

Gbor, J.W.T. (1978). Mdugh u Tiv man mnyer ve ken Benue State. Zaria: Gaskiya.

Gousmett, C. (1996). Introduction to a Christian worldview: A course in thinking Christianly about the whole of life. Retrieved January 31, 2017 from http://allofliferedeemed.co.uk/Gousmett/CGWorldviewManual.pdf.

Interpol (2006). A guide to names and naming practices. Retrieved July 7, 2019 from https://www.fbiic.gov/public/2008/nov/Naming_practice_guide_UK_2006.pdf.

Iyortyom, B.D. (1993). Tiv language and culture. Abuja: Femi Nigeria. 
Koerner, E. F. K. (2002). On the sources of the 'Sapir Whorf Hypothesis'. In Edward Sapir: Critical assessments of leading linguists (2007). Ed. E.F.K. Koerner. London: Routledge.

Kraft, C.H. (1989). Christianity with Power: Your Worldview and Your Experience of the Supernatural (Ann Arbor: Servant Publications. Los Angeles: University of California.

Makar, T. (1994). The history of political change among the Tiv in the $19^{\text {th }}$ and $20^{\text {th }}$ Centuries. Enugu: Fourth Dimension Press.

Meiring, B.A. (1993). The syntax and semantics of geographical names, pp269-289 in P.S. Hattingh, N. Kadmon, P.E. Raper and I. Booysen (Eds.) Training course in toponym for Southern Africa. University of Pretoria.

O,Donnel, N. (2008). Linguistic relativity and the Sapir-Whorf Hypothesis: The influence of language on cognition and the implications for Second Language Acquisition and Bilingualism. University of Dublin, Trinity College. Retrieved July 28, 2019 from https://www.scss.tcd.ie/undergraduate/computer-science-language/bacsll_web/ODonnell0708.fyp.pdf.

Sapir, E. (1956). Language, culture and personality (ed. D G Mandelbaum): Berkeley

Tiav, T.A. (2012). Nigerian names as enactments of the human essence: An analysis of Tiv personal names. Makurdi Journal of Language and Literature, 2(1), 164-173.

Udu, T.T. (2009). Tiv language: A reference book. Kaduna: Labari Publishers.

Uko, I.I. (2004). The socio-cultural implication of Anaan names. Abuja Journal of English and Literary Studies, 1 (1), 98-109.

Vittmann, Günter, 2013, Personal Names: Function and Significance. In Elizabeth Frood and Willeke Wendrich (eds.), UCLA Encyclopedia of Egyptology, Los Angeles. http://digital2.library.ucla.edu/viewItem.do?ark=21198/zz002dwqr7.

Whorf, B. L. (1956), Ed. J.B. Carroll Language, Thought and Reality Cambridge, Mass. MIT Press.

Windt-Val, B. (2012). Personal names and identity in literary contexts. In B. Helleland, C.-E. Ore \& S. Wikstrøm (eds.) Names and Identities, Oslo Studies in Language 4(2), 2012. 273-284. 